\title{
Model Inquiry Berbasis Jelajah Alam Sekitar untuk Meningkatkan Hasil Belajar Siswa SD
}

\author{
Yuyun Dwi Haryanti ${ }^{1}$, Yeni Dwi Kurino² dan Ujiati Cahyaningsih ${ }^{3}$ \\ yuyundwiharyanti18@gmail.com¹, yenidwi_kurino@yahoo.com², ujiati.dikdas13.uny@gmail.com ${ }^{3}$
}

\begin{abstract}
Student learning outcomes are still low which have not been developed optimally in the learning process. Learning still emphasizes the cognitive realm while the affective and psychomotor domains of students are ruled out. The purpose of this study was to improve learning outcomes including the cognitive, affective, and psychomotor domains of fifth grade students at elementary school of Sukarajakulon IV. This research is a Class Action Research covering the steps: planning, implementing, observing, and reflecting. Data collection techniques used were tests, observations, and documentation. Data were analyzed descriptively quantitative and qualitative. In the initial conditions students' mastery learning only reached 30\%, the first cycle of student learning completeness increased to $75 \%$, and the second cycle of student learning completeness reached 95\%. The results of the study show that through Inquiry Model Based on Roaming Nature around can significantly improve student learning outcomes.
\end{abstract}

Keywords: inquiry models, roaming nature around, learning outcomes

Abstrak: $\quad$ Hasil belajar siswa masih rendah dimana belum dikembangkan secara optimal dalam proses pembelajaran. Pembelajaran masih menekankan pada ranah kognitif sedangkan ranah afektif dan psikomotorik siswa dikesampingkan. Tujuan penelitian ini adalah untuk meningkatkan hasil belajar meliputi ranah kognitif, afektif, dan psikomotorik siswa kelas V di SD Negeri Sukarajakulon IV. Penelitian ini merupakan Penelitian Tindakan Kelas meliputi langkah-langkah: perencanaan, pelaksanaan, pengamatan, dan refleksi. Teknik pengumpulan data yang digunakan adalah tes, observasi, dan dokumentasi. Data dianalisis secara deskriptif kuantitatif dan kualitatif. Pada kondisi awal ketuntasan belajar siswa hanya mencapai 30\%, siklus I ketuntasan belajar siswa meningkat menjadi 75\% dan siklus II ketuntasan belajar siswa mencapai 95\%. Hasil Penelitian menunjukkan bahwa melalui model Inquiry Berbasis Jelajah Alam Sekitar dapat meningkatkan hasil belajar siswa secara signifikan.

Kata Kunci: $\quad$ model belajar, jelajah alam sekitar, hasil belajar

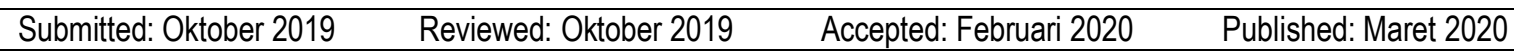

\footnotetext{
1 Universitas Majalengka

2 Universitas Majalengka

3 Universitas Majalengka
} 


\section{PENDAHULUAN}

$\mathrm{P}$ emerintah saat ini memberlakukan Kurikulum 2013 khususnya di Sekolah Dasar. Kurikulum 2013 menitikberatkan pada keseimbangan kompetensi. Standar kompetensi lulusan mencakup pengembangan ranah afektif (sikap), pengetahuan (kognitif), dan keterampilan (psikomotor) yang dielaborasi untuk setiap satuan pendidikan (KEMENDIKBUD RI, 2016). Ketiga ranah tersebut penting dimiliki siswa sekolah dasar dimana perlu dikembangkan secara seimbang kompetensi tersebut melalui proses pembelajaran. Hal ini senada dengan pendapat Setiadi (2016) bahwa pelaksanaan penilaian pada Kurikulum 2013 secara eksplisit meminta para guru di sekolah seimbang dalam melakukan penilaian di tiga ranah domain yaitu ranah kognitif, afektif, dan psikomotor sesuai dengan tujuan pembelajaran yang hendak diukur. Penilaian hasil belajar dilakukan melalui evaluasi dari hasil belajar meliputi ranah kognitif, ranah afektif dan ranah psikomotor (Rusdiana, Sumardi, \& Arifiyanto, 2016).

Penilaian memiliki peranan penting terhadap kesuksesan pendidikan. Penilaian sebagai upaya yang dilakukan oleh guru dalam memantau perkembangan dalam pencapaian kompetensi siswa serta perbaikan hasil belajar siswa. Penilaian dilakukan oleh guru dari awal pembelajaran sampai akhir pembelajaran secara terus menerus sehingga dapat diperoleh penilaian yang objektif. Semakin banyak penilaian yang dilakukan guru, maka semakin banyak informasi yang diperoleh guru dalam melakukan perbaikan proses pembelajaran (Hadiana, 2015). Bertemali dengan pendapat tersebut bahwa seorang guru melakukan penilian harus objektif sehingga dapat mengukur kemampuan hasil belajar siswa yang sesungguhnya.

Abidin (2016) berpendapat bahwa penilaian sebagai pengembangan pembelajaran. Penilaian menempatkan diri sebagai pemandu kegiatan pembelajaran. Baik buruknya penilaian sangat berkaitan dengan tepat dan tidak tepatnya penilaian. Berkaitan dengan hal tersebut selayaknya guru dalam melakukan penilaian pembelajaran dengan mengumpulkan data untuk mengambil keputusan hasil belajar siswa. Hasil belajar bukan hanya ditentukan pada ranah kognitif. Sejalan dengan pendapat Martina Khodijah dan Syarnubi (2019) bahwa kebiasaan belajar tidak hanya bergantung pada pengetahuan tetapi sikap dan keterampilan belajar memiliki pengaruh yang cukup besar dalam menentukan prestasi belajar siswa.

Berdasarkan hasil observasi saat pembelajaran berlangsung di SD Negeri Sukarajakulon IV masih terlihat siswa mayoritas mengerjakan lembar kerja siswa masih menekankan pada kognitif saja sedangkan penilaian sikap dan keterampilan belum dilakukan secara maksimal. Siswa lebih banyak menulis apa yang ada dibuku catatan untuk merekam informasi yang diperoleh. Hal ini dapat dilihat pada daftar nilai siswa penilaian pengetahuan lebih dominan dibandingkan sikap maupun keterampilannya. Penilaian sikap dan psikomotor belum optimal dilakukan oelh guru. Penilaian sikap dan keterampilan bersifat subjektif karena tidak terlihat aktivitas guru melakukan penilaian saat pembelajaran. Hal ini juga pada perangkat pembelajaran penilaian sikap dan psikomotor belum dikembangkan oleh guru. Hal ini diperkuat melalui analisis pada nilai ulangan siswa diperoleh hasil belajar yang belum memenuhi kriteria keberhasilan dimana baru mencapai $30 \%$ (9 siswa dari 30 siswa) yang mencapai ketuntasan belajar. Kondisi seperti inilah perlu dilakukan perbaikan pembelajaran karena kriteria keberhasilan baik apabila mencapai 85\% (Trianto, 2014).

Guru dalam proses pembelajaran harus memperhatikan karakteristik siswa sekolah dasar. Burhaein (2017) menyebutkan bahwa Siswa sekolah dasar memiliki karakteristik senang bermain, senang bergerak, senang berkelompok. dan senang praktik langsung. Senang bermain bermakna bahwa proses pembelajaran melibatkan aktivitas bermain bagi siswa namun tetap mengacu pada ketercapaian materi ajar. Senang bergerak bermakna bahwa siswa sekolah dasar mudah jenuh dan 
tidak bertahan duduk yang berjam-jam kemungkinan duduk tenang maksimal mencapai 30 menit. Senang berkelompok bermakna bahwa siswa senang berkelompok untuk menyelesaikan tugas bersama teman sebaya atau seumuran. Senang praktik langsung bermakna bahwa proses pembelajaran siswa lebih senang praktik bukan teoritik.

Guru dapat menerapkan model pembelajaran yang sesuai di kelas untuk mengatasi permasalahan yang dihadapi dalam meningkatkan hasil belajar siswa. Model Inquiry berbasis jelajah alam sekitar sebagai salah satu model pembelajaran yang sesuai dengan karakteristik siswa sekolah dasar untuk meningkatkan hasil belajar siswa. Model Inquiry berbasis jelajah alam sekitar adalah model yang memberikan kebebasan dan pengalaman belajar bermakna kepada siswa secara konkret untuk melakukan penyelidikan melalui pengamatan langsung objek yang dipelajari (Hadi, Susantini, \& Agustini, 2018; Nugroho, Margareta, \& Abdullah, 2019). Proses berpikir siswa dalam memproses, menyimpan, dan menggunakan informasi untuk merespons tugas atau berbagai situasi di lingkungan. Proses berpikir inilah sebagai karakteristik siswa yang digunakan untuk menghadapi situasi yang dihadapi. Sesuai pendapat (Margunayasa, Dantes, Marhaeni, \& Suastra, 2019), The cognitive style is a way an individual uses in processing, storing and using informationto respond to a task or various kinds of situations in the environment. Cognitive style is a characteristic of personality that is relatively permanent, so that it can be used to explain an individual's behavior in facing various situations. Peranan guru sangat penting dalam pembelajaran. Peran guru dalam pembelajaran sebagai mentor dalam proses pengambilan keputusan. Siswa dan guru bekerjasama dalam merumuskan masalah dan mengembangkan jawaban. Siswa melakukan penyelidikan secara terus menerus sampai menemukan konsep dan materi secara mandiri.

Permasalahan diatas, perlu dilakukan guru dalam meningkatkan hasil belajar siswa Sekolah Dasar melalui model model inquiry berbasis alam sekitar dalam proses pembelajaran. Guru memiliki peran penting dalam mencapai tujuan pembelajaran agar siswa memiliki kompetensi ranah kognitif, ranah afektif dan ranah psikomotor.

\section{METODE PENELITIAN}

Penelitian dilakukan di SD Negeri Sukarajakulon IV kecamatan Jatiwangi kabupaten Majalengka. Subjek penelitian siswa kelas $V$ sebanyak 30 siswa yang terdiri dari 14 siswa perempuan dan 16 siswa laki-laki. Penelitian ini merupakan jenis penelitian tindakan kelas (classroom action research) atau dikenal dengan sebutan PTK. Penelitian yang digunakan mengacu pada model Kemmis dan Mc. Taggart dimana memiliki empat langkah penelitian yaitu perencanaan, pelaksanaan, observasi dan refleksi (Suyadi, 2010). Tahap perencanaan dilakukan dengan menyiapkan semua perangkat pembelajaran Model Inquiry berbasis jelajah alam sekitar meliputi sebagai berikut: 1) Recana Pelaksanaan Pembelajaran (RPP), 2) Materi Ajar, 3) Media Pembelajaran, 4) lembar observasi guru dan siswa, dan 5) Evaluasi. Tahap pelaksanaan adalah tahap dimana mengimplementasikan perangkat pembelajaran Model Inquiry berbasis jelajah alam sekitar pada proses pembelajaran. Tahap observasi dilakukan pada proses pembelajaran Model Inquiry berbasis jelajah alam sekitar untuk mengungkap kelemahan pembelajaran dilihat pada pengamatan pada guru dan siswa. Tahap refleksi merupakan kegiatan perenungan kembali mengenai hasil observasi untuk dilakukan perbaikan pada siklus selanjutnya.

Teknik analisis data menggunakan deskriptif kualitatif dan kuantitatif. Deskriptif kualitatif berupa hasil observasi guru dan siswa yang dilakukan oleh observer yang ditulis pada lembar observasi guru dan siswa. Hasil observasi mendeskripsikan kelemahan dan kelebihan baik guru dan siswa selama proses pembelajaran pada siklus I dan siklus II. Deskriptif kuantitatif berupa hasil belajar siswa yang dianalisis melalui evaluasi pada akhir pembelajaran. Evaluasi dilakukan dengan menggunakan soal pilihan ganda sebanyak 10 butir soal, esai sebanyak 5 butir soal dan uraian sebanyak 5 butir soal. 
Hasil tes dianalisis untuk mengetahui peningkatan hasil belajar siswa dilihat secara klasikal dan individu. Hasil tes belajar siswa dikatakan berhasil atau meningkat apabila mencapai ketuntasan $80 \%$.

\section{HASIL DAN PEMBAHASAN}

Hasil penelitian ini dilakukan dalam 2 siklus, masing-masing siklus dilakukan langkah-langkah penelitian perencanaan, pelaksanaan, observasi, dan refleksi. Hasil penelitian dapat diuraikan sebagai berikut:

Siklus I

Pada siklus I dilakukan pada hari Rabu dan Jumat, 2 dan 4 Mei 2018 pada pukul 09.30-10.40 WIB. Adapun materi yang disampaikan pada pembelajaran tentang Sumber Daya Alam. Tahap Perencanaan dilakukan dengan mempersiapkan perangkat pembelajaran berupa Rencana Pelaksanaan Pembelajaran (RPP), Bahan Ajar, Media dan Alat Peraga, Lembar soal, lembar observasi guru dan siswa. Tahap Pelaksaanaan dilakukan sesuai dengan RPP dengan mengacu model inquiry berbasis jelajah alam sekitar. Kegiatan awal pembelajaran dilakukan dengan mengkondisikan siswa di kelas dengan cara: 1) memberi salam, 2) menanyakan kabar siswa, 3) mengabsen siswa, 4) apersepsi, 5) menyampaikan tujuan pembelajaran, dan 6) memotivasi siswa. Kegiatan Inti dilakukan guru dengan cara mengekplor pengetahuan siswa mengenai materi yang dibahas. Siswa mengamati video yang ditampilkan guru kemudian guru memberikan pertanyaan yang berkaitan dengan materi tersebut. Siswa diberi kesempatan bertanya mengenai materi yang disajikan. Untuk memperdalam pengetahuan siswa, guru membagi siswa kedalam beberapa kelompok secara heterogen untuk berkeliling disekitar lingkungan sekolah mengenai sumber daya alam apa saja yang ditemukan. Siswa berdiskusi serta mempresentasikan hasil temuan untuk didiskusikan di dalam kelas. Pada kegiatan akhir pembelajaran siswa menyimpulkan materi yang telah dipelajari. Untuk mengetahui hasil belajar siswa mengerjakan soal tes. Guru memberikan umpan balik mengenai hasil tes siswa. Selain itu guru memberikan tindak lanjut kepada siswa.

Tahap Observasi adalah tahap pengamatan yang dilakukan oleh observer. Posisi duduk observer dalam melakukan pengamatan berada di bangku belakang sebelah kanan. Observer mencatat temuan yang muncul sebagai kelemahan dan kelebihan dalam proses pembelajaran baik guru maupun siswa pada lembar observasi. Namun, kelemahan guru dan siswa yang ditulis pada lembar observasi. Adapun hasil observasi guru dan siswa dapat diuraikan pada Tabel 1 berikut ini:

\section{Tabel 1. Rekapitulasi Hasil Observasi Guru dan Siswa Siklus I}

\begin{tabular}{lllll}
\hline & Observasi Guru & \multicolumn{3}{c}{ Observasi Siswa } \\
\hline Guru melibatkan siswa untuk & Masih ditemukan beberapa siswa (15 siswa \\
berkeliling lingkungan yang ada di & dari 30 siswa atau 50\%) masih \\
sekitar sekolah namun belum optimal & mengandalkan teman kelompoknya dalam \\
dalam melakukan pengawasan & mengerjakan tugas. & \\
terhadap siswa sehingga ditemukan \\
siswa yang mengandalkan temannya.
\end{tabular}

Berdasarkan hasil observasi guru dan observasi siswa masih ditemukan kelemahan dalam proses pembelajaran. Kelemahan tersebut juga berdampak pada hasil belajar siswa sesuai hasil tes siswa baik individu maupun klasikal. Untuk lebih jelasnya dapat dilihat pada Tabel 2 berikut ini:

\section{Tabel 2. Hasil Belajar Siswa}




\begin{tabular}{lll}
\hline \multicolumn{1}{c}{ Siklus } & \multicolumn{1}{c}{ Tuntas } & \multicolumn{1}{c}{ Belum Tuntas } \\
\hline Pra siklus & $30 \%$ ( 9 siswa dari 30 siswa) & $70 \%$ ( 21 siswa dari 30 siswa) \\
Siklus I & $75 \%$ (22 siswa dari 30 siswa) & $25 \%$ (8 siswa dari 30 siswa) \\
\hline
\end{tabular}

Pada Tabel 2 diatas, dapat dilihat bahwa pembelajaran yang dilakukan di kelas berdasarkan kelemahan guru dan siswa memberikan dampak pada hasil belajar siswa dimana siswa. Apabila dibandingkan pada pra siklus hanya $30 \%$ siswa yang tuntas belajar sedangkan pada siklus I menggunakan model inquiry berbasis jelajah alam sekitar mencapai $75 \%$ naik sekitar $45 \%$.

Tahap Refleksi merupakan evaluasi dari kegiatan perencanaan, pelaksanaan dan observasi. Adapun hasil refleksi pada siklus I adalah sebagai berikut: 1) proses pembelajaran masih belum kondusif sehingga guru perlu melakukan perbaikan bagaimana membuat siswa untuk kondusif di kelas, 2) guru perlu memberikan bimbingan kepada siswa secara menyeluruh, 3) Hasil belajar siswa hanya mencapai $75 \%$ haal ini belum mencapai kriteria keberhasilan yaitu $80 \%$.

Siklus II

Pada siklus II tahap perencanaan dan pelaksanaan masih seperti yang dilakukan pada siklus I hanya beda subpokok bahasan yang dibahas namun masih dalam materi Sumber Daya Alam. Tahap perencanaan dilakukan menyusun perangkat pembelajaran RPP, Bahan Ajar, Media video sumber daya alam, alat peraga, lembar soal, lembar observasi guru dan lembar observasi siswa. Tahap

Pelaksaanaan dilakukan pada hari Rabu dan Jumat, 30 Mei dan 1 Juni 2018 pada pukul 09.30-10.40 WIB. Pelaksanaan pembelajaran menggunakan model inquiry berbasis jelajah alam sekitar. Kegiatan awal pembelajaran dilakukan dengan mengkondisikan siswa di kelas dengan cara: 1) memberi salam, 2) menanyakan kabar siswa, 3) mengabsen siswa, 4) apersepsi, 5) menyampaikan tujuan pembelajaran, dan 6) memotivasi siswa. Kegiatan Inti dilakukan guru dengan cara mengekplor pengetahuan siswa mengenai materi yang dibahas secara lebih menarik. Siswa mengamati video yang ditampilkan guru kemudian guru memberikan pertanyaan yang berkaitan dengan materi tersebut. Siswa diberi kesempatan bertanya mengenai materi yang disajikan. Untuk memperdalam pengetahuan siswa, guru membagi siswa kedalam beberapa kelompok secara heterogen untuk berkeliling disekitar lingkungan sekolah mengenai sumber daya alam apa saja yang ditemukan. Siswa berdiskusi serta mempresentasikan hasil temuan untuk didiskusikan di dalam kelas. Setelah itu, guru memberikan penghargaan bagi kelompok terbaik. Pada kegiatan akhir pembelajaran siswa menyimpulkan materi yang telah dipelajari. Untuk mengetahui hasil belajar siswa mengerjakan soal tes. Guru memberikan umpan balik mengenai hasil tes siswa. Selain itu guru memberikan tindak lanjut kepada siswa dengan memberikan Pekerjaan Rumah (PR).

Tahap Observasi dilakukan oleh observer yang duduk di bangku belakang sebelah kiri dan berkeliling mengamati kegiatan diskusi siswa. Observer mencatat temuan baik guru maupun siswa pada lembar observasi. Adapun hasil observasi guru dan siswa dapat diuraikan pada Tabel 3 berikut ini:

Tabel 3. Rekapitulasi Hasil Observasi Guru dan Siswa Siklus II

\begin{tabular}{|c|c|}
\hline Observasi Guru & Observasi Siswa \\
\hline $\begin{array}{l}\text { Guru mengawasi siswa secara } \\
\text { menyeluruh baik dalam kegiatan } \\
\text { kelompok maupun individu pada } \\
\text { kegiatan mengamati lingkungan sekitar }\end{array}$ & $\begin{array}{l}\text { Siswa lebih mandiri dalam mengerjakan } \\
\text { tugas kelompok maupun individu. }\end{array}$ \\
\hline
\end{tabular}




\author{
sekolah. \\ Guru selalu membimbing siswa yang Siswa kondusif dalam mengerjakan tugas \\ membutuhkan bantuan.
}

Berdasarkan hasil rekapitulasi observasi guru dan observasi siswa sudah lebih baik dari siklus II dimana siswa menjadi mandiri dan kondusif dalam mengerjakan tugas. Begitu juga perhatian guru kepada siswa lebih menyeluruh. Guru berkeliling memberikan bantuan pada siswa yang membutuhkan. Hasil belajar siswa berdasarkan hasil tes dapat dilihat pada Tabel 3 berikut ini:

\title{
Tabel 4. Hasil Belajar Siswa
}

\begin{tabular}{lll}
\hline \multicolumn{1}{c}{ Siklus } & \multicolumn{1}{c}{ Tuntas } & \multicolumn{1}{c}{ Belum Tuntas } \\
\hline Pra siklus & $30 \%$ ( 9 siswa dari 30 siswa) & $70 \%$ ( 21 siswa dari 30 siswa) \\
Siklus I & $75 \%$ (22 siswa dari 30 siswa) & $25 \%$ (8 siswa dari 30 siswa) \\
Siklus II & $95 \%$ (28 siswa dari 30 siswa) & $5 \%$ (2 siswa dari 30 siswa) \\
\hline
\end{tabular}

Pada Tabel 4 diatas, dapat dilihat bahwa pembelajaran yang dilakukan di kelas pada silkus II memberikan hasil yang signifikan dimana hasil belajar siswa meningkat dari pra siklus sampai siklus II hal ini adanya perbaikan pembelajaran yang dilakukan guru berdasarkan kelemahan yang diperbaiki dalam proses pembelajaran. Hasil belajar siswa meningkat dari pra siklus ke siklus II mencapai $65 \%$. Hasil belajar siswa pada siklus II sudah mencapai kriteria keberhasilan dimana sudah mencapai lebih dari $85 \%$ yaitu pada siklus II mencapai $95 \%$.

Berdasarkan hasil penelitian bahwa model inquiry berbasis jelajah alam sekitar dapat meningkatkan hasil belajar siswa sekolah dasar. Hasil belajar siswa dianalisis melalui evaluasi setelah proses pembelajaran. Hasil belajar yang diteliti meliputi ranah kognitif, afektif, dan psikomotor. Peningkatan hasil belajar siswa dapat dilihat pada pra siklus, siklus I dan siklus II. Untuk lebih jelasnya dapat dilihat pada Gambar 1 sebagai berikut:

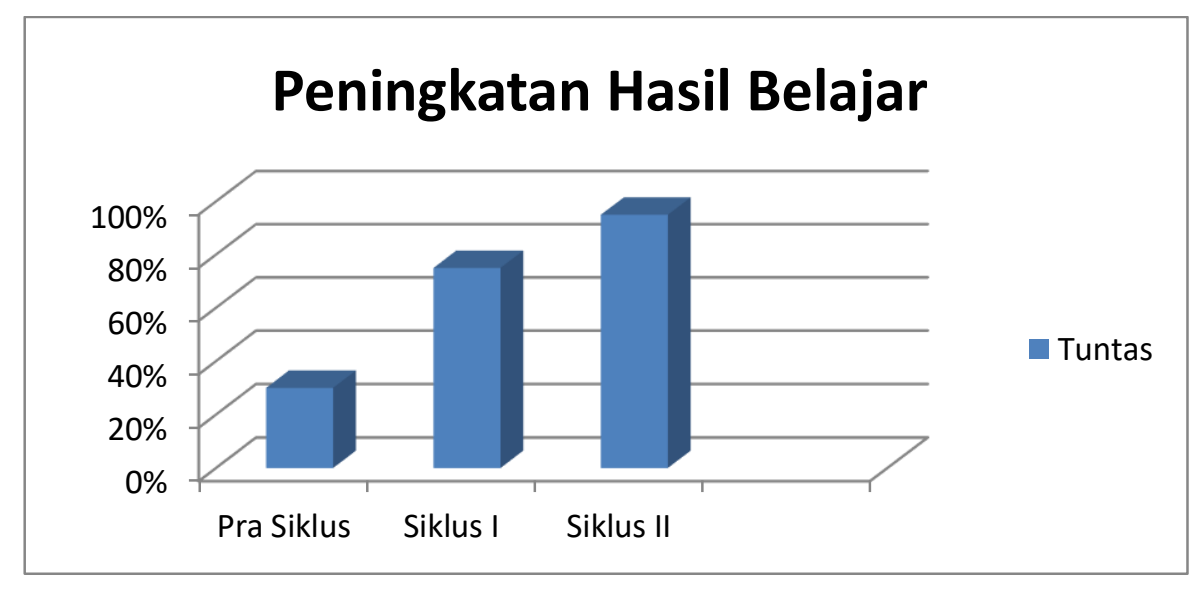

Gambar 1. Peningkatan Hasil Belajar Siswa

Pada gambar 1 diatas, bahwa Pelaksanaan pembelajaran dengan menggunakan model inquiry berbasis jelajah alam sekitar sudah efektif diimplementasikan dalam proses pembelajaran di kelas. Guru memiliki peran penting dalam pembelajaran di kelas bahwa menggunakan model model inquiry berbasis jelajah alam sekitar dapat memberikan dampak pada aktivitas siswa di kelas (Nurmilla \& Priyono, 2018). Pembelajaran tersebut juga dapat berdampak positif bagi siswa maupun guru. Bagi siswa dapat membangun pengetahuan, sikap dan keterampilan. Hal ini sesuai dengan pendapat 
Trianto (2014:80) bahwa "Pembelajaran Inquiry menekankan aktivitas siswa belajar secara maksimal untuk mencari dan menemukan jawaban sendiri dari sesuatu yang dipertanyakan melalui pengembangan kemampuan berpikir secara sistematis, logis, kritis siswa sehingga menumbuhkan sikap percaya diri.

Proses pembelajaran di kelas model inquiry berbasis jelajah alam sekitar sesuai dengan karakteristik siswa sekolah dasar. Siswa dilibatkan langsung dalam proses penyelidikan pada lingkungan sekitar. Sebelum siswa melakukan penyelidikan guru mengeksplor pengetahuan yang dimiliki siswa melalui video yang ditampilkan oleh guru. Siswa merespon sesuai dengan apa yang mereka ketahui. Untuk memperdalam materi siswa dilibatkan lagsung dalam penyelidikan pada lingkungan sekitar sehingga siswa menemukan sendiri apa yang mereka temukan. Hal ini membuat siswa lebih tertantang dalam menemukan konsep sendiri mengenai materi yang diajarkan. salah satu hal penting yang perlu dilakukan guru dalam kegiatan pembelajaran di sekolah adalah bagaimana membuat siswa dapat belajar dengan baik dan menyenangkan (Syofyan \& Sumantri, 2019).

Hasil belajar siswa meningkat secara signifikan melalui model inquiry berbasis jelajah alam sekitar tidak terlepas dari peranan guru. Senada dengan pendapat (Akiba, Murata, Howard, \& Wilkinson, 2019) bahwa "Teacher learning communities have been promoted as a promising approach to promote system wide improvement of teaching and student learning". Kolaborasi guru dalam melakukan penelitian tindakan kelas sebagai sistem pendekatan dalam meningkatkan pengajaran dan pembelajaran siswa. Kolaborasi dilakukan untuk mengamati temuan sebagai kelemahan guru dan siswa sebagai refleksi. Hasil refleksi sebagai dasar untuk melakukan perbaikan pembelajaran. Guru memahami kelemahan dalam proses pembelajaran sesuai hasil observasi. Kelemahan siswa dapat teratasi sesuai dengan temuan saat proses pembelajaran. Melalui temuan inilah guru dapat melakukan perbaikan pembelajaran dan penilaian hasil belajar siswa SD.

\section{KESIMPULAN DAN SARAN}

Berdasarkan hasil penelitian di SD Negeri Sukarajakulon IV kecamatan Jatiwangi kabupaten Majalengka dapat disimpulkan bahwa Model Inquiry Berbasis Jelajah Alam Sekitar dapat meningkatkan hasil belajar siswa. Guru dalam proses pembelajaran di kelas memberikan dampak yang signifikan pada hasil belajar siswa sehingga diperlukan persiapan perangkat pembelajaran sehingga dapat menunjang pembelajaran secara maksimal.

\section{DAFTAR PUSTAKA}

Abidin, Y. (2016). Revitalisasi Penilaian Pembelajaran: dalam Konteks Pendidikan Multiliterasi Abad ke21. Bandung: PT. Refika Aditama.

Akiba, M., Murata, A., Howard, C. C., \& Wilkinson, B. (2019). Lesson study design features for supporting collaborative teacher learning. Teaching and Teacher Education, 77, 352-365. https://doi.org/10.1016/j.tate.2018.10.012.

Burhaein, E. (2017). Aktivitas Fisik Olahraga untuk Pertumbuhan dan Perkembangan Siswa SD. Indonesian Journal of Primary Education Vol 1 No 1 (2017) 51-58. https://doi.org/10.17509/ijpe.v1i1.7497.

Hadiana, D. (2015). Penilaian Hasil Belajar untuk Siswa Sekolah Dasar. Jurnal Pendidikan Dan Kebudayaan, 21(1), 15. https://doi.org/10.24832/jpnk.v21i1.173

Hadi, S. A., Susantini, E., \& Agustini, R. (2018). Training of Students' Critical Thinking Skills through the implementation of a Modified Free Inquiry Model. Journal of Physics: Conference Series, 947(1). https://doi.org/10.1088/1742-6596/947/1/012063. 
KEMENDIKBUD RI. (2016). Peraturan Menteri Pendidikan Dan Kebudayaan Republik Indonesia nomor 22 tahun 2016. Kemendikbud RI.

Margunayasa, I. G., Dantes, N., Marhaeni, A. A. I. N., \& Suastra, I. W. (2019). The effect of guided inquiry learning and cognitive style on science learning achievement. International Journal of Instruction, 12(1), 737-750. https://doi.org/10.29333/iji.2019.12147a.

Martina, Khodijah, N dan Syarnubi. (2019). Pengaruh Lingkungan Sekolah Terhadap Hasil Belajar Siswa Pada Mata Pelajaran Pendidikan Agama Islam Di Smp Negeri 9 Tulung Selapan Kabupaten Oki. Jurnal PAI Raden Fatah, Vol.1 No.2. https://doi.org/10.19109/pairf.v1i2.3235.

Nugroho, E. K., Margareta, R., \& Abdullah, M. (2019). Pendidikan Konservasi Berbasis Jelajah Alam Sekitar (Jas) Di Sekolah Dasar Se-Kelurahan Sekaran Kecamatan Gunungpati Kota Semarang. Rekayasa, 16(2), 187-192. https://doi.org/10.15294/rekayasa.v16i2.17511.

Nurmilla, M. F., HB, F. P. M., \& Priyono, B. (2018). The Effectiveness of Guided Inquiry Learning with JAS Approach on the Learning Result of Environmental Pollution Material Volume 2, Nomor 1, April 2018, pp: 105 -109. Journal of Biology Education. https://doi.org/10.15294/jbe.v7i3.26466.

Rusdiana, H., Sumardi, K., \& Arifiyanto, E. S. (2016). EVALUASI HASIL BELAJAR MENGGUNAKAN PENILAIAN AUTENTIK PADA MATA PELAJARAN KELISTRIKAN SISTEM REFRIGERASI. Journal of Mechanical Engineering Education Vol.1, No.2, Desember 2014 https://doi.org/10.17509/jmee.v1i2.3814.

Setiadi, H. (2016). PELAKSANAAN PENILAIAN PADA KURIKULUM 2013. Jurnal Penelitian Dan Evaluasi Pendidikan Volume 20, No 2, Desember 2016 (166-178) https://doi.org/10.21831/pep.v20i2.7173.

Suyadi. (2010). Penelitian Tindakan Kelas. Yogyakarta : Diva press.

Syofyan, H., MS, Z., \& Sumantri, M. S. (2019). PENGEMBANGAN AWAL BAHAN AJAR IPA DI SEKOLAH DASAR. JPD: Jurnal Pendidikan Dasar P-ISSN. https://doi.org/doi.org/10.21009/JPD.010.06.

Trianto. (2014). Mendesain Model Pembelajaran Inovatif, Progesif, dan Kontektual Konsep, Landasan, dan Implementasinya pada Kurikulum 2013 (Tematif Integratif /KTI), Jakarta: Prenademed Group.

How to cite: Haryanti, Y. D., Kurino, Y. D., Cahyaningsih, U. (2020). Model inquiry berbasis jelajah alam sekitar untuk meningkatkan hasil belajar siswa SD. Teknodika, 18 (1), 16-23. DOI: https://doi.org/10.20961/teknodika.v18i1.34962 